\title{
The Globe on Saturday, the World on Sunday: Toronto Weekend Editions and the Influence of the American Sunday Paper, 1886-1895
}

\author{
Sandra Gabriele \\ University of Windsor \\ Paul S. Moore \\ Ryerson University
}

\begin{abstract}
Between 1886 and 1895, the Sunday newspaper in U.S. cities became a cauldron for an emerging mass, popular culture - one with reach into Canada. The concurrent development of weekend newspapers in Toronto, Canada, distinguished local innovations against the unspecified, general influence of the "American Sunday paper." The Sunday World and the Saturday Globe followed and refuted, respectively, the ideal set by the American Sunday paper, but together defined Canadian weekend leisure reading. The reference in Canadian newspapers to an idealized American Sunday model offers an example of an emergent continental mass popular culture where cultural forms circulated, and were transformed, producing interesting local specificities.
\end{abstract}

Keywords: Communication history; Print culture/Journalism history; Newspapers; Popular Culture

Résumé : Entre 1886 et 1895, dans de nombreuses villes américaines, le journal $\mathrm{du}$ dimanche est devenu le foyer d'une culture de masse émergeante dont l'influence s'est étendue jusqu'au Canada. À Toronto, le journal du samedi et du dimanche se sont développés simultanément, engendrant certaines innovations locales effectuées par rapport à l'influence générale du « journal du dimanche américain ». Ainsi, le Sunday World et le Saturday Globe ont suivi l'idéal prôné par le journal du dimanche américain, bien que par la suite ils l'aient délaissé. Ensemble, ces deux journaux ont défini la lecture de loisir de fin de semaine au Canada. Dans les commentaires sur le modèle idéalisé du journal du dimanche américain offerts par les journaux canadiens, on perçoit une culture de masse émergeante où l'expression culturelle a pu circuler et se transformer, avec comme résultat la création de spécificités locales de grand intérêt.

\footnotetext{
Sandra Gabriele is Assistant Professor at the University of Windsor where she teaches in the Department of Communication, Media and Film and Women's Studies Program, 401 Sunset Avenue, Windsor, ON N9B 3P4. Email: 'gabriele@uwindsor.ca! Paul Moore is Assistant Professor in the Department of Sociology at Ryerson University, JOR-306, 350 Victoria Street, Toronto, ON M5B 2K3. Email: Ins
}

Canadian Journal of Communication, Vol 34 (2009) 337-358

(C)2009 Canadian Journal of Communication Corporation 
Mots clés : Histoire de la communication; Culture de l'imprimé; Histoire du journalisme; Journaux; Culture populaire

In October 1885, a prominent news dealer and stationer in Toronto, John P. McKenna, moved into new premises on Yonge Street near King Street, in the heart of the newspaper publishing district. McKenna's daily advertisement promoted "The Modern Bookstore" in the city's working-class penny dailies, highlighting the latest arrivals for sale: new editions and installations of popular novelists, illustrated weeklies from Britain and Europe, and monthly magazines from Canada and elsewhere. For two months early in 1886, McKenna boasted, "We Can Supply Any Newspaper or Magazine Published," and by the end of the year imported newspapers became the shop's specialty. By the close of the decade, McKenna's advertising only rarely noted stationery, novels, and British papers, but "Sunday Papers from all the Principal Cities in America" were routinely noted as available in Toronto. ${ }^{1}$ American Sunday papers, especially from the border towns of Buffalo and Detroit, largely displaced the earlier alternative of illustrated Sunday weeklies from England. These ads record the period when supplements to the weekend editions of American daily papers took shape as "the Sunday paper," providing a cornerstone of popular leisure, even across the border in a Canadian metropolis. As this format developed, it did so alongside and in response to a range of other printed matter, such as installations of novels, magazines, and special ledgers. ${ }^{2}$

Canadian newspapers did not strictly follow either the British or American traditions of Sunday publication. ${ }^{3}$ In fact, they were largely restricted by both custom and law from publishing or selling their papers on Sundays at all. Regardless of those injunctions, the market for American Sunday papers in Toronto shown in McKenna's advertising helps explain the 1889 emergence of the Saturday Globe as a distinctly Canadian form of weekend leisure, as well as the introduction in 1891 of the Sunday World as a first Canadian seventh-day edition. ${ }^{4}$

These observations point to other critical shifts in the circulation of newspapers that were part of the larger landscape in the closing decades of the nineteenth century. The promotion of American newspapers by one of the largest and best advertised news dealers in downtown Toronto indicates a growing level of interest on the part of Toronto readers for American fare. Competition among newspapers in Toronto was defined not only by local papers, but also by an increasing influx of printed materials of all kinds from around the world. Newspapers themselves began to promote and design their weekend editions to address leisure and mass cultural pursuits as much as political and economic affairs. This is true of Toronto papers at exactly the same time McKenna's ads show it for American. The coincidence of the emergence of the American Sunday and Canadian Saturday editions is partly explained through technological innovations, economic competition, and professional standardization; but the more or less concurrent development of the weekend edition across North America also signals a cultural shift in the role of the newspaper in everyday lives, at home, in the city, and in society overall.

We trace this expanding circulation of newspapers by examining the birth of a popularized weekend paper, primarily using the cases of the Saturday Globe and the Sunday World in Toronto, with some attention to the Buffalo Express. 
Although the material exigencies of distribution in the late nineteenth century underwrote the possibility of increased circulation, we also insist on understanding circulation as an empirical and conceptual problem. Clearly, the simplification of the circulation figure (that is, the amount of papers sold) is not enough to account for changing readerships and publics. In what ways did the material conditions that facilitated greater distribution and circulation permit the newspaper to become a product of popular culture? With competition and influences from a variety of sources and places, what is the work of the weekend edition? Is it a local paper? National? Popular? What do these categories mean given these changing conditions?

The promotional rhetoric used in the World and the Globe to publicize their weekend editions (Sunday and Saturday, respectively) was the self-actualization of an encounter with an imagined American ideal. It is important to stress, however, that American papers did not force an immediate response from the Canadian papers under review here. Rather, the idea of the American popular press worked powerfully in the imaginations of Canadian editors and readers alike. This period is particularly important since the papers considered were defining themselves against an ideal American Sunday paper that in practice was still in flux, diverse in form and content, and soon transformed by the introduction of Pulitzer's and Hearst's versions of a mass Sunday paper (Campbell, 2001; Schudson, 1978). American publishing nonetheless worked powerfully in the rhetoric of Toronto papers as an often-unexplained benchmark or referent. In mobilizing the American press as a cultural precedent, Toronto newspapers developed weekend editions that repudiated the American model by staking out cultural niches and readerships, yet at the same time validated their influence by incorporating the same technological and visual design trends. The similarity with developments in American cities like Buffalo and the widespread availability of American papers in Canada indicates that the straw figure of the American Sunday paper was at once a nationalist and a commercial manoeuvre.

This engagement produced a distinct cultural form - the weekend editionthat deserves its own analytic and theoretical treatment apart from the daily newspaper. Although the development of the weekend edition is clearly contingent on and influences the daily paper, previous analyses of the daily paper fail to account for the specificity of what was happening on the weekend. ${ }^{5}$ Using theories of circulation, we highlight the interstices and moments of encounter that eventually form a new whole in the weekend edition as a mix of traditional elements (news, political interventions) and new logics (mass readership, leisure reading), and thus an innovative mode of intervening in culture. We begin by explicating more clearly the theoretical position of the weekend edition of the newspaper in previous literature and borrow from the recent literature on the concept of circulation to provide a theoretical basis upon which to understand the historical phenomenon. We proceed to trace how weekend papers in Toronto developed identities for themselves, thus marking themselves as unique parts of a larger network of weekend leisure. ${ }^{6}$

In constituting mass publics out of mass readerships, the newspaper was key to an emerging popular culture tied to the rhythms of the industrial work week. 
The Saturday Globe developed a nationalist version of the weekend paper as a competitive move in a marketplace that included American Sunday papers, even as it adopted many of the same design features. An opposite strategy came from the Sunday World, which embraced the popular sensationalism of the American style, even its Sunday dateline, despite lagging behind in the technological ability to adopt illustrations and expand its size. While each paper engaged with the specter of the American popular press differently, both encouraged readers to engage with a weekend edition as an essential part of leisure time, a routine part of the workweek.

\section{The weekend newspaper as supplement and the social space of readers}

Canadian strategies of differentiation from American popular culture, such as the weekend newspapers under review here, were the surface effects of an increasingly continental economic and cultural marketplace (Brown \& Cook, 1974; Rutherford, 1993). American industry's "visible hand" came to the forefront of the age of empire in the late nineteenth century (Chandler, 1977; Hobsbawm, 1987), with mass-marketed commodities emblematic of the resulting cultural changes (Domosh, 2006; Rydell \& Kroes, 2005; Strasser, 1995). The cultural success of the mass market cannot be reduced to the effect of population growth, massive expansion of cities, and better transportation networks that bound America into a marketplace and facilitated economies of scale (Barth, 1980; Nasaw, 1999). The new, mass-distributed commodities also provided a "socially prismatic" (Taylor, 1992, pp. 83-84) popular culture for a newly heterogeneous mass society.

The commercial basis and spread of modernity was often challenged by moral, social, and labour reform movements that sought better conditions for workers and families, and protections for traditional values, especially Sabbath observation. These reforms often fed back into the integrative force of popular culture when more leisure time was gained (Peiss, 1986; Rosenzweig, 1983). New pastimes emerged with vaudeville, restaurants, amusement parks, and the bicycle, which immediately became the target of new concerns and regulations (Erenberg, 1984; Moore, 2008; Nasaw, 1999; Norcliffe, 2001). Holiday time took on new, pressing importance as workers gained more time off, and the value of holidaying as a recuperative activity led the growth of travel excursions and vacation resorts (Gabriele, 2006; Heron \& Penfold, 2005; Jasen, 1995). Traditional forms of reading were commodified into magazines and syndicated serial fiction (Brake, 2001; Damon-Moore, 1994; Garvey, 1996; Johanningsmeier, 1997). Illustration and humour became routes to fortunes for editors like Frank Leslie and John Bengough and through new genres like comic strips (Cumming, 1997; Gordon, 1998; Pearson, 1990).

In Canada, however, the creep of American popular culture was met with a backlash. Religious and moral reform bodies were created, paying special attention to immigration and settlement and the protection of young women migrating to cities (Marks, 1996; Strange, 1995; Valverde, 2008). Moreover, leisure activities especially were targeted as both opportunities to be tempted by the pleasures and evils of the city and a possibility for redemption. Reading appropriate litera- 
ture and engaging in appropriate activities afforded possibilities for asserting how modern life ought to be lived (Kinahan, 2007; Pederson, 1996). The Lord's Day Alliance in particular was largely successful in keeping the Sabbath a day of rest in Canada, especially in Ontario. Though they and other groups lost the battle against streetcars running in Toronto and other cities (Armstrong \& Nelles, 1977), they did manage to reaffirm prohibitions against almost all Sunday labour and trade, including newspaper publishing, in federal legislation passed in 1906. Sunday in Canada ironically became more provincial in character, heightened in surveillance and regulation with legislation and prohibitions at every level of government (Laverdure, 2004; Strange \& Loo, 1997). In Toronto, the Saturday Globe and the Sunday World each worked within this broad social context to forge the profitability of the American model of popular culture with concern for Canadian particularity.

Any shift in the cultural role of the newspaper reflected changes in how newspapers circulated. New technologies helped to publish more news: telegraphs helped gather and disseminate different and larger volumes of news faster and from farther away; new presses allowed newspapers to publish more papers in a shorter period of time; Linotype machines allowed more type to be set more quickly; and cheaper paper meant more pages could be added for a lower cost. The economics of newspapers also changed as advertising revenue paid for a higher proportion of these costs. In turn, the need for more readers to maximize potential advertising revenue meant more street hawking within cities as well as distribution well beyond the city limits through the post and train (Barth, 1980; Kaplan, 2002).

As a result, several fascinating developments came about in Toronto. A special school for newsboys was established by Hester How in 1885 responding specifically to the higher truancy rates of newsboys. This school accommodated flexible hours of attendance, needed because "when an 'Extry' [extra] . . . was pronounced a runner shouted the call through the classroom door, at which the whole class bolted, each pupil returning only when his papers had been sold" (Toronto Board of Education, 1964, pp. 1-2). The growing distribution and circulation of newspapers in the city meant officials of all kinds needed new ways to regulate newsboys' activities. Newsboys' fervent attempts to sell papers quickly to a captive audience led the Toronto Railway Company to widely publicize a strict rule forbidding newsboys from boarding streetcars without paying (Telegram, October 11, 1897). Demand for newspapers on trains and streetcars also points to a greater mobility of readers, and thus a more comprehensive flow of reading matter (Henkin, 1998). Circulation of Toronto newspapers expanded to include the entirety of southwestern Ontario when the Globe launched its own special "Globe Fast Train" in March 1887, allowing delivery hours earlier than competitors relying on regular postal train schedules. The promotional rhetoric of this development was fulsome, such as the Globe's claim for its first anniversary that the Fast Train was an "achievement unparalleled in journalism" (March 3, 1888 , p. 5). Such innovative ways to circulate papers, and the attendant issues that arose in response, demonstrate the need to think about the movement and influence of the newspaper beyond the city printed on its masthead, as much as they suggest a need to rethink the shifting geography of newspaper production. 
The popular daily newspaper forged community identities among its readers, as historians such as Gunther Barth (1980) and David Paul Nord (2001) have demonstrated, but the weekend paper encouraged taking part in a wider mass culture. Beginning in the 1880 s, the size of newspapers, especially weekend papers, ballooned as they included vastly more advertising while attracting larger audiences. The popularization of the American press began in the 1830 s with the Jacksonian era penny papers, which, for the first time, reported everyday life from the point of view of the popular rather than the political (Barnhurst \& Nerone, 2001; Lehuu, 2000; Williams, 1961). By the late 1880s, newspapers began to self-consciously court mass audiences, in part to defray the investment in larger overhead costs associated with the introduction of faster presses, the capacity to reproduce illustrations and photographs, greater flexibility in the layout of the page, and new reporting techniques that delivered on the promise of now-often-screaming headlines (Nerone \& Barnhurst, 2003; Walkom, 1983). Nerone \& Barnhurst (2003) describe this popularization of the newspaper in the United States as a transition from a printer's to a publisher's newspaper, from the partisanship of politics to a marketplace metaphor characterized by independent, rational choices. By the 1890 s, this marketplace became a department store, offering a variety of goods developed through a whole new set of newsgathering techniques and presented in a more systematically organized form. Much like the department store democratized luxury (Laermans, 1993; Williams, 1982), the segmented newspaper separated politics from leisure and entertainment, thereby making less distinct the class identities of its readers (Curran, 1978). Although such papers were later codified and dismissed as "yellow journalism" (especially in the later 1890s, when Hearst and Pulitzer were in direct competition with each other), the last decade of the nineteenth century was an altogether tumultuous and exciting period in both American and Canadian journalism.

The newspaper was, and remains, part of popular culture, not separate from it (Dahlgren \& Sparks, 1992). As Raymond Williams (1968) has shown, the meaning of "culture" changed in response to changes in other concepts like industry, democracy, and art. While newspapers are often connected to industry and political culture, Williams' genealogy demonstrates how changes in the meanings of those concepts in the nineteenth century were deeply tied to each other. The newspaper does not merely mimic or mirror in its pages what was already popular. Newspapers struggled to find their own popular journalistic form; they were part of the emergence of modernity, not just a vehicle for it. The mass popularization of the newspaper through the continual reference to an American ideal suggests a cultural and political struggle over what was distinctively Canadian about a newspaper when its forms were increasingly looking more like American ones. Holding up the American model while simultaneously distinguishing themselves from it, the Canadian papers under review here became more heavily illustrated (more popular) and sensationalist (more populist), and also had specialized columns that addressed precisely those previously disenfranchised in democracy, like the working classes and women. On the other hand, the expansion of readerships into a more indiscriminate mass happened by addressing everyone as consumers in a segmented marketplace. Hence the feminized address of the women's 
page, and also feminized products such as serialized novels, drama, and fashion notes; the children's page, and also comic strips and music sheets; the labour column, and also classifieds and sports - all alongside the continuing prominence of politics and commerce.

Expanded weekend newspapers with wide distribution and readerships were key to the financial stability of newspapers from the latter part of the nineteenth century; yet they have been ignored, or even castigated, by much of the research on newspaper history especially in Canada (for example, see Rutherford, 1982; Sotiron, 1997). In his work connecting newspapers to cultural and social history, Raymond Williams (1961) observed that "there is a surprising tendency to accept certain formulas about the development [of the press], which seem less to arise from the facts of press development than to be brought to them" (p. 173). Which formulas, then, leave the weekend edition unformulated in newspaper history? Michael Schudson (1997) names an anti-commercial bias, democratic functionalism, and declinism as "common troubles" in histories of American journalism, helping explain the lack of attention to the popular leisure of the Sunday paper (p. 463). James Curran (1993) points out that both liberal and Marxist models of critique assume that entertainment features either distract the public, provide consumer gratification, or sedate their readers. These models presume a stable and (pre)determined relationship between the form of newspapers, readers, and uses by readers.

The weekend edition has been neglected as a popular object because it challenges theoretical understandings of the role of journalism that treat readers as rational citizens in the pursuit of information within the democratic public sphere, rather than (or, also as) consumers in pursuit of leisure. The relegation of the popular as unimportant within some journalism history contains a hint of discomfort with the more feminine, the more juvenile, the more working-class parts of the paper. Inserted supplements such as illustrated sections, commemorative posters, half-page song sheets, and serialized fiction all pull at the edges of what a newspaper is supposed to be and do. In this sense, the weekend edition is theoretically and literally a supplement, in the Derridean sense. ${ }^{7}$ Reified as an extraneous supplement, journalism history - supported by the institutional practices of Canadian libraries and archival institutions that fail to microfilm inserts, special editions, and other so-called ephemera - continues to define its object of study as the daily newspaper. The vital role of the newspaper in modernity must understand the often excluded and maligned elements of the weekend edition, its links to other cultural forms, and its self-conscious call to its readers. A hybrid cultural form that temporarily held a range of popular discourses, practices, forms, and images, the weekend edition staged debates about what the "popular" would look like and who the "people" were.

We claim the newspaper animated modernity, establishing a link between the mass market and the democratic public sphere, especially in the weekend supplement. By providing something for everyone, newspapers not only made mass readerships and circulations, but also actually created the mass public and mass culture. In other words, the newspaper, in its emergent commercialized form, and especially in the weekend edition, built a social space of readers that was deeply 
connected to the social, political, and economic bases of modernity. Following the logic of Benedict Anderson's (1983) "imagined communities," Michael Warner (2002) has suggested that publics only come into existence in relation to texts and their circulation: "Without the idea of texts that can be picked up at different times and in different places by otherwise unrelated people, we would not imagine a public as an entity that embraces all the users of that text, whoever they might be" (p. 51). Lee \& LiPuma (2002) further insist circulation is "a cultural process with its own forms of abstraction, evaluation, and constraint, which are created by the interactions between specific types of circulating forms and the interpretive communities built around them" (p. 192).

Modes of address in constituting particular publics are especially important here in delimiting how circulation functions. Warner further explains: "We might recognize ourselves as addressees, but it is equally important that we remember that the speech was addressed to indefinite others; that in singling us out, it does so not on the basis of our concrete identity, but by virtue of our participation in the discourse alone, and therefore in common with strangers" (2002, p. 58). By the end of the nineteenth century, and especially in the weekend papers, personalized modes of address (for instance, the constant reference to the "dear reader" and use of the first person in stories) became more prominent even as the puffery of circulation figures signalled the readership was an undifferentiated mass. The study of weekend papers must contend with this paradoxical relationship between a personalized address and a mass circulation.

Rather than assuming a priori the relationship between cultural forms and readers, technological innovation, or economic modes of production, cultural forms should be understood as assemblages, constantly changing and transforming, though with a solidity and predictability to them still (Gaonkar, 2002; Straw, in press). Contemporary studies of the circulation of culture have called attention to the underlying processes that support the movement around the world of interrelated forms of contemporary culture, capital, knowledge, and risk (Lee \& LiPuma, 2002). Like other historians, we are mindful that those processes began in the nineteenth century when new modes of circulating information emerged that were transformative to everyday life, ways of knowing and feeling. Tracing this movement of information and how it was locked up in changing forms of culture and commerce performs a journalism history of "past forms of imagination, of historical consciousness" (Carey, 1974, p. 4; see also Carey, 2009). It is at this cultural level that the social space of newspaper readers is formed, where "the readers" are formed as a social and empirical category, and where newspapers become linked to other kinds of circulation-like commodities and people.

As Raymond Williams long ago recognized in The Long Revolution (1961), the history of journalism is marked by the refiguring of a wide range of cultural forms, including ballad sheets, chapbooks, and almanacs. Later theorists of circulation have called this process transfiguration, the repurposing or "refunctioning" (Gaonkar \& Povinelli, 2003, p. 396) of a text or form or discourse within a different setting. The concept suggests that circulation (and exchange, for that matter) is more than a mere process of transmission, but one that is constitutive (Lee \& LiPuma, 2002). One key effect of technologies is to produce recognizable identi- 
ties for these connections, giving them shape, substance, even affect (Slack \& Wise, 2005). This is precisely the process we call attention to in the following section, as we show how both the Saturday Globe, and to a lesser extent the Sunday World, interpreted and transfigured the illustrated supplements, techniques of address, serialized novels, columns, and technologies of presentation that characterized American papers entering Canada. The encounter of different forms within the weekend edition transformed its function into a key element of mass culture, thus with wider influence than the political sphere-and specifically able to cross political borders, such as into Canada.

\section{The Globe on Saturday}

On May 11, 1889, the Globe began including a four-page illustrated supplement, bringing its Saturday edition to 20 pages for the same three-cent cost as its 12page weekday editions. Announced on the front page with a degree of pomp, the paper framed the expansion as a new benchmark in weekend reading: "To-day's Globe presents to its many thousands of readers perhaps the best Saturday paper ever issued in Canada." It continued by suggesting it "compared not unfavorably with the best Sunday issues of the great metropolitan dailies of the United States." Although American newspapers, especially their Sunday supplements, were available in Toronto either through news dealers like McKenna or by subscription, the Globe addressed their opposition as a foreign, spectral ideal, as an option being rejected. In the following weeks, the Globe would simultaneously invoke the favourable appeal of American papers as a form of interesting leisure reading on the weekend, while staking out a distinctively nationalist flavour to its own formulation: "To-day's Globe is not eclipsed even by the great Sunday papers of the chief American cities . . . It is preeminently a Canadian paper. Its contents appeal particularly to a Canadian constituency" (May 25, 1889, p. 1). And again, "This great issue of The Globe is not a mere reprint of American papers. It is not a mere rehash of cheap sensations gathered from the four corners of the earth. It is a Canadian paper, dealing with Canadian topics and written by Canadians for Canadians. Its contents are clean and wholesome" (June 1, 1889, p. 1). These early promotional notes about the illustrated supplements provide us with the Globe's reflexive positioning of the expanded features, a hint at the editorial decision-making and marketing strategy, particularly within its own market. Though it would follow a similar formula to American papers, its careful distinction from them is evidence of circulation at work.

The Globe classed its opposite as a blanket genre-American Sunday papers - even before the norms of popular weekend supplements in the United States had been standardized. Without acknowledging that many American newspapers were circulating widely and freely across the border in Canada, the Globe used the Canadian public's knowledge and attraction to the popularity of American Sunday papers to mark itself as something different: Canadian. Without naming domestic competitors, it distinguished itself from other Toronto newspapers that relied heavily on reprinted clippings and syndicated dispatches from the U.S. This nationalist strategy was a competitive move to expand its readership well beyond the city of Toronto, but more importantly it constituted the Globe's social space of its readership as having a national scope, an imagined 
community. The promotional purpose and exaggerated rhetoric are not simply what W. J. Campbell (2001) notes as a commonplace "penchant for self-promotion" (p. 8) in the news publishing field. This particular self-promotion aimed for an expanded readership through constituting a nationalist, mass public, and did so by distinguishing that form of leisure from the indiscriminate popular appeal of the American mass public as constituted through the secular Sunday leisure of American papers. The Globe implicitly activated the ideals of democracy by explicitly addressing its readership as spanning all classes of society, but Canadian society rather than the alternative of secular mass society.

Unlike the sensationalism of American papers, which so easily offended and rarely truly appealed to all, the Globe claimed to offer something of "interest and instruction for all classes of the community" (May 11, 1889, p. 1). The newly illustrated material of the Saturday supplement would use the techniques of entertainment to educate and use a variety of topical columns to represent a collectivity of class, rather than segment its readers. The first Saturday supplement, for instance, contained an illustrated history of London, Ontario; sketches of the Canadian Pacific Railway entry to Toronto; religious commentary; international, British, and Western Canadian correspondence; "Chatty Women"; and sporting events, rounded out with civic, farming, and editorial columns (May 11, 1889). "Its contents," the paper continued the week following, "touch the interests of all classes of Canadians. It is a paper for businessmen, politicians, workingmen, farmers, and for the home" (May 18, 1889, p. 1). Specific features such as its expanded size and new illustrations characterized this appeal to the mass, as did its difference from, some might even say deference to, the populist style of American papers, whose appeal was in effect equivocated with mass-marketed, popular culture. Transfiguring these innovations within a nationalist framework, highlighting explicitly its provincial content with a civic and historical bent, the Globe positioned itself as a national newspaper (this indeed became its moniker) and helped constitute a distinctly Canadian, pastoral, and instructive brand of popular leisure.

If the substantive content of the Saturday Globe was distinctly Canadian insofar as it was pastoral and instructive, the formal design elements of the supplementary pages relied on the very same display of modern novelty as its peers in the United States. In its competition domestically and against the emerging influence of the American Sunday paper, the Globe relied on illustrations and a more flexible layout of the page; specialized columns, such as its women's page, for particular segments within the mass readership; strongly narrated non-fiction feature stories; telegraphed news coverage from great distances; and mass distribution throughout Ontario by railroad express and by postal train even farther. This was the same combination of technique and technology that allowed the transmission of the "threat" from south of the border in the first place. The Globe's strategy in response makes it evident how there is thus another factor, a cultural or nationalist factor that is muted for American newspapers until they cross the border: the imagined community of a particular newspaper's readership.

Within a month of starting the new supplement, the Globe's dominion across the country was proclaimed: "The Saturday Globe has already made itself famous 
all over Canada" (June 15, 1889, p. 1), with a final boastful claim that it was "already established as the greatest of Canadian newspapers. The issue of to-day must increase its prestige and enhance its popularity" (June 22, 1889, p. 1). Thus, the Globe did not entirely deny the importance of popular culture, but instead formed a specifically Canadian approach combining popularity with prestige, taking stewardship for the entire population, all of its classes, through instruction and historical grounding rather than catering to the lowest common denominator of commercial populism. Within two months of introducing the supplement, its masthead was changed to The Saturday Globe, explicitly marking its distinction from the weekday issues (July 6, 1889).

\section{The Globe's marketplace}

The nationalist rhetoric surrounding the introduction of the Saturday Globe served another purpose besides distinguishing the paper from its American competition. On first glance in formal terms, there was nothing new to Toronto here. For three years already, other city newspapers had been printing similar content in their Saturday editions. The real innovation in the Globe was to include predictability and thus anticipation in the package of illustrated features, women's and other columns, and syndicated fiction. The self-referential puffery of the promotional introductions in May and June 1889 explained the Saturday Globe as a planned compilation that could be leisurely read every Saturday (and eagerly awaited every week). Even after the rhetoric faded, the Saturday Globe masthead continued, and it is exactly that scheduled elevation of the weekend that was the novelty here among Toronto's total six daily newspapers. All previous supplements were occasional. The special four-page illustrated broadsheet with the Saturday Globe masthead survived for some 15 years, being replaced by a tabloid "magazine section" in 1904. Much like the New York Tribune and Times, the Globe's magazine insert refrained from adopting colour or comic pages.

The Saturday Globe's dominant feature for its first few years was illustrated profiles of smaller cities and towns throughout Ontario and across Canada, thus shoring up its efforts to expand circulation by appealing to Toronto's hinterland as part of its dominion. This was a direct copy of a special feature begun in the Daily Mail three years earlier, in March 1886. The difference was that the Daily Mail's town profiles were each promoted as special editions, published without any routine schedule (usually every two weeks, but sometimes two consecutive weeks, sometimes two months apart).

Among Toronto newspapers, the first response to the Daily Mail's illustrated special editions had come from one of the penny papers. The Telegram began publishing city landmark sketches on Labour Day weekend in 1886, a clear sign that the weekend paper was deeply tied to leisure time and activities. The first few installations were illustrated tours of parks around the city and at the annual Industrial Exhibition. Illustrated histories of more than 100 churches in the city soon followed, a feature that took on the title "Landmarks of Toronto" when it turned to secular institutions like fire halls, court houses, shops, and mansions. Although these appeared in the Telegram for more than a decade, the size and degree of illustration varied greatly, from a small note without a sketch to more than a page with nine or more sketches. John Ross Roberston, the Telegram's pub- 
lisher, eventually collected them in a series of editions, updating them as new sketches were completed (see Robertson, 1894, 1904, 1908, 1914). The Telegram had popularized its Saturday edition very early (for example, printing sheet music weekly in 1885), but it did not keep up with new printing technologies as they became available. Although it had a jump-start of several years on the Globe's Saturday illustrated supplement, by the 1890s the Telegram looked old-fashioned (Rutherford, 1975).

Trying to gain back the market share it had lost earlier to the penny papers, the Daily Mail and the Globe marched almost lockstep in developing new Saturday features and heavily investing in new technologies (Walkom, 1983). The Mail was first to augment and illustrate the banners for its women's page (January 3, 1891). The Globe did the same in December, adding the novelty of a Children's Page that same week, which the Daily Mail soon followed several months later. Both adopted half-toned photographs for their Saturday supplements simultaneously on March 28, 1891. Both increased the price of their Saturday editions to five cents within weeks of each other. ${ }^{8}$ Although there was still diversity within the Toronto market, the adoption of these features in close proximity to each other suggests how tightly the circulation of ideas about culture was tied to its forms, in this case notions of popularity and ways of addressing readerships. With the Globe and the Daily Mail being the two largest circulation morning papers in the Toronto market during this time, the tight exchange of cultural forms across these papers indicates how deeply tied cultural circulation is to the circulation of capital.

If the Telegram lagged behind in terms of design, another penny paper, the News, thoroughly adopted illustrated elements in the early 1890s in a successful bid to briefly obtain, by a wide margin, the highest circulation of any paper in town. The News introduced a series of illustrated banners and new feature columns, usually months in advance of the Daily Mail or the Globe. Perhaps not surprisingly, its first illustrated banner graced the classified "People's Page" (August 27, 1890). Its appeal was working-class features, briefly renaming its classifieds as "For the Help of the Unemployed." Interestingly, the News preempted the hallmark of weekend reading for the morning papers, the women's and children's pages, by publishing them on Friday, resplendent with large illustrated banners.

With such visually modern design already established, a new editor in 1893 began adopting Pulitzer-style promotion of growing circulation figures. The News then purchased an existing illustrated weekly paper, the Saturday Ledger, and moved over many of its special features to launch the five-cent Saturday News in February 1894, creating even further consistency across this market. ${ }^{9}$ The Saturday News was also clearly invested in the larger print culture of the time, going so far as to promote its pages as "a newspaper magazine for Sunday reading" (October 7, 1898, p. 1). Even its weekday edition included a "Daily Magazine" column. This Saturday paper gave the News a regularly published seventh edition, an exceptional situation shared by only one other paper in all of Canada, the Toronto World, which had introduced a five-cent Sunday edition in 1891. The Sunday World was distributed by legal necessity on Saturday evenings, 
and we will return to its special niche momentarily. First, there is another "Canadian" weekend paper to consider.

\section{The Canadian Buffalo Express}

The 1892 inaugural McKim's Canadian Newspaper Directory begins with a Canadian Customs table of tariffs related to the printing and publishing industry. Every import required to do business in Canada had some fee apportioned, around $20 \%$ of the cost, from fashion plates and photographs to printing type to presses. One specific item noted is a $25 \%$ tariff on "newspapers or supplemental editions, partly printed and intended to be completed and published in Canada." However, finished foreign magazines and newspapers could be imported for free. Thus, if American newspapers were to syndicate supplements to an otherwise Canadian paper, there would be a hefty fee, but importing a Canadian edition of a split-run American newspaper would avoid customs tariffs altogether. At least one paper did so: the Buffalo Sunday Express.

In the late 1880 s, there were five daily papers in Buffalo, four of which had Sunday editions. The most elaborate of these was the Sunday Express. In 1885, there was still little to distinguish the five-cent Sunday Express from its three-cent weekday companions. Neither included much illustration, nor special columns beyond "Society" or "Literature." In October 1885, the Sunday edition expanded to 12 pages, but at first without any promotion or any novel visual or organizational features. Within weeks, however, the additional four-page supplement settled into a heavily illustrated "cover," providing pages 1 and 2, then 11 and 12 outside a more traditionally laid out eight-page paper "inside." While the idea of a Sunday supplement was already established, the format of corralling illustrations to the cover sheet is somewhat distinct, for example from Pulitzer's New York World at the time. The separate printing of that cover, perhaps on a different press and apparently with higher quality paper, allowed the Buffalo Express to quickly become far more visually spectacular than its Buffalo competitors. The Sunday Times, lagging in circulation, focused instead on developing columns geared toward specialized readerships: fashion, humour, sports, society, and amusements. The Sunday News, far ahead in circulation, was a more conservative paper visually in this period. Not surprisingly, McKenna's news dealer advertisements in Toronto often single out the Buffalo Sunday Express as of special appeal to Toronto readers (News, September 6, 1886).

Late in 1887, the eight-page "inside" of the Buffalo Sunday Express split into three editions, all sharing the four-page illustrated "cover": a Buffalo city paper had maximal advertising; beginning on November 20, 1887, a regional edition had less advertising space but was supplemented by columns reporting from Rochester, Syracuse, and throughout western New York and northwestern Pennsylvania; and beginning December 18, 1887, a Canadian edition which still had ads for Buffalo shops, but alongside columns reporting from Toronto, Ottawa, Hamilton, and a smattering of smaller cities throughout southwestern Ontario. ${ }^{10}$ All three editions shared a column of Canadian notes, "Doings in the Dominion," indicating that the interest in the cross-border edition was not necessarily only in Ontario. If the Saturday Globe used its Canadian content to make a national newspaper that was distinct from an American Sunday paper, then what type of paper 
is the Canadian edition of the Buffalo Sunday Express? Seeming to demonstrate the openness of the border around Niagara Falls, this paper in particular constitutes its Canadian readership as part of a continental, international marketplace sharing a common culture with the United States, quite literally able to be shared downtown in Buffalo.

\section{The World on Sunday}

The Toronto newspaper market did develop its own American-style Sunday paper, and the niche was filled with the first seventh-day paper in Canada: the Sunday World bowed on Queen Victoria's Holiday, May 24, 1891. To compete with the prestige and popularity of the Globe and the Daily Mail, and to stake out another position from the other penny papers, the World entirely rejected the option of instructive, historical profiles of provincial themes and civic landmarks. In addition to the daring move of having a Sunday edition in Canada, the World's weekend stories and content embraced the metropolitan modernity of American sensationalism. Flouting the sanctity of the Sabbath while leering at the secular world of crime and consumption instantly gave the Sunday World a niche to itself, a distinction so indiscrete that no other paper in Canada had a seventh edition with a Sunday dateline for as long as the Sunday World published, until 1924. The Sunday dateline was not illegal in itself, since its printing and distribution happened on Saturday evening, "delivered in any part of the city by 10 p.m." This was typical for Sunday editions of American papers, too, except that in Toronto it would have been actually illegal to sell or deliver it on Sundays at all. Although copies were "sent East and West by all trains leaving Toronto on Saturday night," it remains unclear if that ensured subscription delivery by midnight, allowed pickup at depots, or meant some had to wait until Monday. ${ }^{11}$ The taboo of a Sunday paper in Canada was strong enough that the World actually called it the "Saturday Night Edition" in almost all of its early promotion despite the Sunday dateline.

The Saturday Night Edition was flagged as "Something New in Canadian Journalism ... It is the intention to introduce a lot of interesting features and thereby make [it] the most newsy, the most readable and the most interesting paper published in Toronto. Read It! For Sporting News, for Social News, for Municipal Intelligence and for the Great Events of Every Saturday" (June 4, 1891, p. 8). Curiously, there was really very little original or particularly "newsy" about the new edition. At only four pages, it was actually half the length of the Saturday morning edition, and it sold for five cents, not just five times the cost of a daily edition of the World but initially two cents more than the Globe or the Daily Mail, for far less material. No matter how much of interest, it seems unlikely that the cost was worth the initially slim volume. Any value was clearly tied to the very idea of buying a secular Sunday paper at all. Toronto, again, illuminates an important point about the American weekend paper by contrast: its Sunday dateline was essential to its cultural importance, connoting the secularization of leisure and family time even as it provided a key means of creating it. As exemplified in the Sunday edition, secularization and commercialization can even be linked to the constitutional separation of church and state (specifically unlike in Canada), itself an essential factor in creating the polyglot melting pot in the United States. 
Only a single early issue of the Sunday World remains: a four-page edition from June 7, 1891, perhaps kept because the Saturday-evening deadline provided a scoop that Canada's first prime minister, Sir John A. Macdonald, had died. The paper had almost no illustrations and only one substantial ad (for suburban bungalows), so the journalism itself was presumably what made it newsy and readable. On the front page adjacent to the news of Macdonald's death were sporting scores from the Saturday-afternoon games. Inside were a special feature by an American "Store Window Scientist," a column about prize-fighting (a later staple of the Sunday World's sports coverage), and a feature of tales from Ontario's Kingston Penitentiary and New York's Sing Sing prison. There was a provocative assessment of the latest modish fashion trend of "kickers," women's healed boots, as well as a more conventional column, "The World of Women. Feminine Chat and Wisdom from Various Sources. Their Fads, Fancies, and Fashions. Talk for and About the Gentler Sex." There was also a story coyly reviewing "a rural lassie's queer plaything"- - snakes! - that used the metaphor of Eve in the Garden of Eden and described itself as a "Graphic Description of an Incident of Real Life. This is a Story that Will Thrill the Girls."

Compared to the parochial illustrations of landmarks and historical profiles of provincial towns found in other Toronto weekend editions, the Sunday World paid attention to criminals, curiosities, shopping, fashion, and boxing among its sports. These topics do indeed seem to espouse the sensational, specifically including plenty of American stories. There was no pretense of elevation or instruction; the Sunday World was following the model of American-style popular culture. Readers of this weekend paper were being addressed as part of an international popular culture, in particular attracted to American culture and interested to integrate a continental popular culture into everyday life in Toronto. While not as explicit as the Canadian edition of the Buffalo Sunday Express, with its content and advertising from Buffalo amidst specialized columns from Ontario, the Sunday World similarly facilitated among its readers a continental sensibility. In publishing a "Sunday" paper; in highlighting American content in relation to Toronto topics; in profiling graphic, thrilling, sensational stories; in catering to the whims of fashion and the contests of sport, the Sunday World transfigured this American content into a Canadian paper, but with a readership understood to be integrated into the American mass market and vibrantly part of the modern world of mass culture taking shape across the border. This seems to be echoed by the Buffalo Sunday Express' Canadian edition, which featured advertising for American stores and events.

Five retained copies of the Sunday World in December 1895 demonstrate the paper still lagged considerably behind its competitors in graphic innovation. It remained a mere eight pages and none were heavily illustrated. Sensationalism and topics from popular culture continued to be its distinguishing features. The choice of stories, urban focus, American content, and focus on leisure-and always also Toronto's only Sunday masthead - all these made the paper somewhat infamous. When a new 24-page tabloid format was introduced on January 20, 1901, the Sunday World celebrated the occasion as a decade-long fight against adversity: "All the one-time prejudice has disappeared: its most appreciative 
friends have come from ancient critics . . . . We believe to-day that the Sunday World as a newspaper, as a reading paper, is more highly spoken of, more lookedfor and more popular, than any single edition of any other paper in Canada" (p. 1). The Sunday World gradually expanded to embrace the printing and journalistic technologies of yellow journalism as well as a similar tone and substantive content. It finally added an illustrated half-toned supplement in 1902, and soon the illustrated supplement was eight broadsheet pages lithographed on heavy, glossy paper. Over the first decade of the twentieth century, the Sunday World, unlike any Toronto paper and more than any other Canadian paper, introduced dozens of special, heavily illustrated columns, for the stage, for fashion, for motoring, and real estate, eventually for moving pictures and radio, often the first and most extensive of such feature pages in the country.

From its introduction in 1891, the Sunday World practically did the opposite of the Globe's embrace of Canadian, nationalist content. Without adopting the newer techniques of illustrated design, nor the modern modes of address through specialized columns, the content of the Sunday World nonetheless focused on commercial, secular metropolitanism, an especially striking array given the short span of just four pages. This was presumably the same type of material that the Globe held up as its counter-example when it reified "American Sunday papers" as its opposite, and it is precisely the type of stories that later became codified as "yellow journalism." Yet it would be wrong to claim the Sunday World simply mimicked American journalism. Within the context of Toronto's deep commitment to the Sabbath, with its active religious communities that strove to fight the creeping secularism of modernity, the publication of American stories or American-style journalism itself was transfigured in this newspaper, providing new political meanings and a broader mode of address that tried to bring Toronto into the continental cultural marketplace.

\section{Conclusion}

In dramatically distinct ways, both the Globe on Saturday and the World on Sunday were influenced by the American press and drew upon public knowledge of the idea of an American Sunday paper even as actual American Sunday papers were still creating their own norms. Yet Toronto was a clearly distinct market in the contours of its popular press. While at least one paper in Toronto embraced more of the elements of the American popular press, even its infamous Sunday dateline, none of them followed the prototypical design of an American Sunday paper; in fact, our research illustrates that such a prototype might not exist in any single paper, even as we turn to American cities to expand our project continentally. What each paper did adopt was a more abstract practice of crafting a community out of their weekend edition's mass readerships, making the "weekend paper" in general a cultural form that was integral to the emerging secular foundation of modernity in leisure and consumption.

These early years of experimentation highlight how precarious these popular forms were as newspapers were desperate to hang on to, and steal away, every possible reader. Though historians value newspapers as records of events, or as sedimented forms of cultural expression and values of a profession not yet fully formed, its producers at the time - and indeed many cultural authorities- 
bemoaned the transience and impermanence of a form that often ended up as wrappers at the fishmongers or simply as waste. The problem of accessing and finding copies of weekend editions today attests to this, even more so since as a mass cultural object, popular papers like weekend editions and Sunday papers were considered too popular and too lowbrow to be worth keeping even many decades later.

As the years progressed, the Globe and the World continued to highlight themselves as engaging, leisurely reads, referring to themselves as "full of fresh and interesting matter" (Globe, January 1, 1892, p. 2) and "the brightest, crispest, most cosmopolitan, most interesting of Canadian weeklies" (World, October 25, 1895 , p. 1). Clearly, the weekend paper was explicitly designed to be popular as it took a different form from the daily edition. That popularity cannot be reduced to circulation wars or mass support for editorial positions. The popularity of the weekend paper, instead, was about appealing to the senses, engaging and entertaining readers. Here the American papers offered a benchmark, but one that would grow increasingly unreliable as the century came to a close and the height of the yellow press was reached. While the Globe increasingly claimed the domain of provincialism and a nationalist voice, the Sunday World finally found its footing in its weekend pages in the twentieth century, further tying its fortunes to the American ideals embodied by its Sunday dateline and tabloid form.

Our study of the popularization of the press, then, attends to self-promoted novelties in the form of newspapers as simultaneously constitutions of the cultures of the masses - the working classes, the newly discovered mass - as well as the cultures of the cultural and political elites. As Stuart Hall (1981) argues, this approach to the study of popular objects places them in a broader context than just resistance or incorporation of one cultural form or another, but one of transformations. The weekend papers in Toronto were built on the regulatory regimes of traditional ideas of propriety and decency, transforming American techniques into something distinctively Canadian, yet ready to become modern, mass, and popular. The newspaper, far from giving up its power, merely transformed it into becoming a cultural authority, one that played a critical function in transforming the cultural landscape of the time. In its appeals to an idea of American content (one it assumed its readers also understood), the Sunday World and the Saturday Globe demonstrated the power of the newspaper as a technology of modernity. Fomenting and idealizing the relationship between particular forms in the newspaper, particular readers that constituted a mass public, and a broader cultural imaginary that invoked its neighbour to the south, the weekend editions were key to a forming continental mass popular culture.

\section{Acknowledgments}

Research funding for this paper was provided through a Social Sciences and Humanities Research Council of Canada Standard Research Grant. Earlier versions of this paper were presented at the annual conferences of the Canadian Communication Association and the Association for Education in Journalism and Mass Communication. The authors would like to thank their respective institutions for additional research funding and our research assistants, Tanya Farr at Ryerson University and Laura Gallant at the University of Windsor. Additionally 
the authors wish to thank Darren Wershler, Gene Allen, and the blind reviewers of this paper for their insights and helpful suggestions.

\section{Notes}

1. The synopsis of J.P. McKenna's advertising is based on its publication in the Toronto News. Similar ads appeared in the Toronto Telegram.

2. As part of the larger SSHRC-funded project on weekend editions throughout North America, we focus on such intermedial connections between the newspaper and other cultural forms, including comics, magazines, film, and radio.

3. Many American papers published seven days a week, often with multiple editions in a day. This tradition was distinct from the British Sunday custom of papers produced only once a week, without a corresponding daily paper. See Kamper (2001) for more on the controversy surrounding the introduction of a seventh daily edition of the New York Herald in London.

4. Note the distinction between a seventh daily edition and a weekly edition. Common in both the United States and Canada, a weekly or "farm" edition compiled highlights from the prior six editions with a particular focus on rural and regional news (Fetherling, 1990). In 1880 in Toronto, the Globe, Daily Mail, Empire, and News all had weekly editions available by postal subscription. The circulation and prestige of the weeklies waned exactly as the Saturday supplements emerged. In 1880, for example, circulations of the Weekly Globe and Weekly Mail were each around 35,000 copies (Ayer \& Son, 1880), well above the daily editions. By 1898, the weekly circulations had dropped to only around 25,000 (Ayer \& Son, 1898). Most Canadian weekly editions have been lost and are not microfilmed, except when they were kept instead of the daily editions in smaller cities.

5. We are thankful to Gene Allen for his reminder about the relationship between the weekend paper and its weekday editions.

6. Nerone \& Barnhurst (2003) suggest that the reliability of the form is precisely what helped to constitute particular publics for a paper, as readers came to depend on and expect a newspaper's form on a day-to-day basis.

7. Jonathon Culler (1982) explains Derrida's concept of "the supplement" as follows: "The supplement is an inessential extra, added to something complete in itself, but the supplement is added in order to complete, to compensate for a lack in what was supposed to be complete in itself . . . the additional extra, also becomes an essential condition of that which it supplements" (p. 104). For a full account of Derrida's ideas, see Derrida (1976).

8. The Daily Mail raised its price on March 4, 1893, with the Globe soon following on April 15, 1893. The Empire, Toronto's youngest paper, aimed for the same market but did not introduce an illustrated section nor half-toned photographs; with the creation of the Mail \& Empire in February 1895, the Daily Mail's format and features were those retained. The parallel development of the Mail \& Empire and the Globe continued for decades, until the formation of the Globe \& Mail in 1933.

9. Like the Saturday Ledger it continued, this special Saturday News (not on the microfilmed copies and to our knowledge all issues lost) was distributed on Friday evenings. The special five-cent Saturday issue seems to have folded around 1900, while the one-cent regular Saturday edition soon included a tabloid "News Magazine," from May 1901 until January 1903, printed in colour and featuring the New York Journal's Katzenjammer Kids comic strip from August 1901 (perhaps the first Canadian newspaper to adopt a syndicated American Sunday comic strip).

10. A decade later, at least one small-town Ontario newspaper included promotional notes for the Buffalo paper: "The Illustrated Buffalo Express finds favor everywhere. A good Christmas present is a year's subscription to this popular journal" (Petrolia Advertiser, December 8, 1897).

11. Preliminary research into the history of Lord's Day Alliance, an advocacy group that was active in protecting Sundays, indicates that newspapers were being sold around the province on Sundays on the train. The Lord's Day Alliance launched an especially vigilant campaign at the turn of the century to have locals arrested who purchased from newsagents who were to sell only to train passengers. Newsagents would frequently sell papers to people waiting on the train platform. Providing newsagents sold their newspapers from the train's stairs and not from the platform, they were not breaking any laws, though the names of those who purchased were frequently noted by members of the alliance and passed on to authorities. 


\section{Newspapers}

Buffalo Express

Daily Mail (Toronto)

Empire (Toronto)

Globe (Toronto)

Globe \& Mail (Toronto)
Illustrated Buffalo Express

Mail \& Empire (Toronto)

New York Herald

New York Journal

New York Times
New York Tribune

News (Toronto)

Saturday Ledger (Toronto)

Telegram (Toronto)

World (Toronto)

\section{References}

Anderson, Benedict. (1983). Imagined communities: Reflections on the origin and spread of nationalism. London: Verso.

Armstrong, Christopher, \& Nelles, Henry Vivian. (1977). The revenge of the Methodist Bicycle Company: Sunday streetcars and municipal reform in Toronto, 1888-1897. Toronto, ON: P. Martin Associates.

Ayer, N.W. \& Son. (1880). N.W. Ayer and Son's American Newspaper Annual. Philidelphia, PA: N.W. Ayer and Son.

Ayer, N.W. \& Son. (1889). N.W. Ayer and Son's American Newspaper Annual. Philidelphia, PA: N.W. Ayer and Son.

Barnhurst, Kevin G., \& Nerone, John C. (2001). The form of news: A history. New York, NY: Guilford Press.

Barth, Gunther. (1980). City people: The rise of modern city culture in nineteenth-century America. New York, NY: Oxford University Press.

Brake, Laurel. (2001). Print in transition, 1850-1910: Studies in media and book history. New York, NY: Palgrave.

Brown, Robert Craig, \& Cook, Ramsay. (1974). Canada, 1896-1921: A nation transformed. Toronto, ON: McClelland \& Stewart.

Campbell, W. Joseph. (2001). Yellow journalism: Puncturing the myths, defining the legacies. Westport, CT: Praeger.

Carey, James W. (1974). The problem of journalism history. Journalism History, 1(1), 3-5, 27.

Carey, James W. (2009). Communication as culture: Essays on media and society (Rev. ed.). New York, NY: Routledge.

Chandler, Alfred Dupont. (1977). The visible hand: The managerial revolution in American business. Cambridge, MA: Belknap Press.

Culler, Jonathan D. (1982). On deconstruction: Theory and criticism after structuralism. Ithaca, NY: Cornell University Press.

Cumming, Carman. (1997). Sketches from a young country: The images of Grip magazine. Toronto, ON: University of Toronto Press.

Curran, James. (1978). The press as an agency of social control: An historical perspective. In George Boyce, James Curran, \& Pauline Wingate (Eds.), Newspaper history from the seventeenth century to the present day (pp. 57-75). London: Constable.

Curran, James. (1993). Rethinking the media as public sphere. In Peter Dahlgren \& Colin Sparks (Eds.), Communication and citizenship: Journalism and the public sphere (pp. 27-57). London: Routledge.

Dahlgren, Peter, \& Sparks, Colin. (1992). Journalism and popular culture. London: Sage.

Damon-Moore, Helen. (1994). Magazines for the millions: Gender and commerce in the Ladies' Home Journal and the Saturday Evening Post, 1880-1910. Albany, NY: State University of New York Press. 
Derrida, Jacques. (1976). Of Grammatology. (Gayatri Chakravorty Spivak, Trans.). Baltimore, MD: Johns Hopkins University Press.

Domosh, Mona. (2006). American commodities in an age of empire. New York, NY: Routledge.

Erenberg, Lewis A. (1984). Steppin' out: New York nightlife and the transformation of American culture, 1890-1930. Chicago, IL: University of Chicago Press.

Fetherling, Doug. (1990). The rise of the Canadian newspaper. Don Mills, ON: Oxford University Press Canada.

Gabriele, Sandra. (2006). Gendered mobility, the nation and the woman's page: Exploring the mobile practices of the Canadian lady journalist, 1888-1895. Journalism: Theory, Practice \& Criticism, 7(2), 175-197.

Gaonkar, Dilip Parameshwar. (2002). Toward new imaginaries: An introduction. Public Culture, 14(1), 1-19.

Gaonkar, Dilip Parameshwar, \& Povinelli, Elizabeth A. (2003). Technologies of public forms: Circulation, transfiguration, recognition. Public Culture, 15(3), 385-398.

Garvey, Ellen Gruber. (1996). The adman in the parlor: Magazines and the gendering of consumer culture, 1880s to 1910s. New York, NY: Oxford University Press.

Gordon, Ian. (1998). Comic strips and consumer culture, 1890-1945. Washington, DC: Smithsonian Institution Press.

Hall, Stuart. (1981). Notes on deconstructing 'the popular.' In Raphael Samuel (Ed.), People's history and socialist theory (pp. 227-240). London: Routledge.

Henkin, David M. (1998). City reading: Written words and public spaces in antebellum New York. New York, NY: Columbia University Press.

Heron, Craig, \& Penfold, Steven. (2005). The workers'festival: A history of Labour Day in Canada. Toronto, ON: University of Toronto Press.

Hobsbawm, Eric. J. (1987). The age of empire, 1875-1914. New York, NY: Pantheon Books.

Jasen, Patricia Jane. (1995). Wild things: Nature, culture, and tourism in Ontario, 17901914. Toronto, ON: University of Toronto Press.

Johanningsmeier, Charles. (1997). Fiction and the American literary marketplace: The role of newspaper syndicates, 1860-1900. Cambridge: Cambridge University Press.

Kamper, David Scott. (2001). Sunday newspapers, class and the struggle for respectability in late Victorian Britain. In Martin Hewitt (Ed.), Unrespectable recreations (Vol. 1, pp. 81-94). Leeds: Leeds Centre for Victorian Studies.

Kaplan, Richard L. (2002). Politics and the American press: The rise of objectivity, 1865 1920. Cambridge: Cambridge University Press.

Kinahan, Anne-Marie. (2007). Cultivating the taste of the nation: The National Council of Women of Canada and the campaign against "pernicious" literature at the turn of the twentieth century. Canadian Journal of Communication, 32(2), 161-179.

Laermans, Rudi. (1993). Learning to consume: Early department stores and the shaping of the modern consumer culture. Theory, Culture and Society, 10(4), 79-102.

Laverdure, Paul. (2004). Sunday in Canada: The rise and fall of the Lord's day. Yorkton, SK: Gravelbooks.

Lee, Benjamin, \& LiPuma, Edward. (2002). Cultures of circulation: The imaginations of modernity. Public Culture, 14(1), 191-213. 
Lehuu, Isabelle. (2000). Carnival on the page: Popular print media in antebellum America. Chapel Hill, NC: University of North Carolina Press.

Marks, Lynne Sorrel. (1996). Revivals and roller rinks: Religion, leisure, and identity in latenineteenth-century small-town Ontario. Toronto, ON: University of Toronto Press.

McKim's Canadian Newspaper Directory. (1892). The Canadian Newspaper Directory. Montréal, QC: A. McKim and Co.

Moore, Paul S. (2008). Now playing: Early moviegoing and the regulation of fun. Albany, NY: State University of New York Press.

Nasaw, David. (1999). Going out: The rise and fall of public amusements. Cambridge, MA: Harvard University Press.

Nerone, John C., \& Barnhurst, Kevin G. (2003). News form and the media environment: A network of represented relationships. Media, Culture and Society, 25(1), 111-124.

Norcliffe, G. B. (2001). The ride to modernity: The bicycle in Canada, 1869-1900. Toronto, ON: University of Toronto Press.

Nord, David Paul. (2001). Communities of journalism: A history of American newspapers and their readers. Urbana, IL: University of Illinois Press.

Pearson, Andrea G. (1990). Frank Leslie's Illustrated Newspaper and Harper's Weekly: Innovation and imitation in nineteenth-century American pictorial reporting. Journal of Popular Culture, 23(4), 81-111.

Pederson, Diana. (1996). Providing a woman's conscience: The YWCA, female evangelicalism, and the girl in the city, 1870-1930. In Wendy Mitchinson (Ed.), Canadian women: A reader, (pp.194-210). Toronto, ON: Harcourt Brace Canada.

Peiss, Kathy Lee. (1986). Cheap amusements: Working women and leisure in turn-of-thecentury New York. Philadelphia, PA: Temple University Press.

Robertson, J. Ross. (1894). Landmarks of Toronto: A collection of historical sketches of the old town of York from 1792 until 1833, and of Toronto from 1834 to 1894. Toronto, ON: J. R. Robertson.

Robertson, J. Ross. (1904). Robertson's landmarks of Toronto: A collection of historical sketches of the old town of York from 1792 until 1837 and of Toronto from 1834 to 1904. Toronto, ON: J. Ross Robertson.

Robertson, J. Ross. (1908). Robertson's landmarks of Toronto: A collection of historical sketches of the old town of York from 1792 until 1833, and of Toronto from 1834 to 1908: Also, three hundred and thirty engravings of places and scenes in Toronto or in connection with the city. Toronto, ON: J. R. Robertson.

Robertson, J. Ross. (1914). Robertson's landmarks of Toronto: A collection of historical sketches of the old town of York from 1792 until 1833, and of Toronto from 1834 to 1914: Also, two hundred and thirty-eight engravings of places and scenes in Toronto or in connection with the city. Toronto, ON: J. R. Robertson.

Rosenzweig, Roy. (1983). Eight hours for what we will: Workers and leisure in an industrial city, 1870-1920. Cambridge: Cambridge University Press.

Rutherford, Paul. (1975). The people's press: The emergence of the new journalism in Canada, 1869-99. Canadian Historical Review, 56(2).

Rutherford, Paul. (1982). A Victorian authority: The daily press in late nineteenth-century Canada. Toronto, ON: University of Toronto Press. 
Rutherford, Paul. (1993). Made in America: The problem of mass culture in Canada. In David H. Flaherty \& Frank E. Manning (Eds.), The beaver bites back: American popular culture in Canada (pp. 260-280). Montréal, QC: McGill-Queen's University Press.

Rydell, Robert W., \& Kroes, Rob. (2005). Buffalo Bill in Bologna: The Americanization of the world, 1869-1922. Chicago, IL: University of Chicago Press.

Schudson, Michael. (1978). Discovering the news: A social history of American newspapers. New York, NY: Basic Books.

Schudson, Michael. (1997). Toward a troubleshooting manual for journalism history. Journalism and Mass Communication Quarterly, 74(3), 463-476.

Slack, Jennifer Daryl, \& Wise, J. Macgregor. (2005). Culture + Technology: A primer. New York, NY: Peter Lang.

Sotiron, Minko. (1997). From politics to profits: The commercialization of Canadian daily newspapers, 1890-1920. Montréal, QC: McGill-Queen's University Press.

Strange, Carolyn. (1995). Toronto's girl problem: The perils and pleasures of the city, 1880-1930. Toronto, ON: University of Toronto Press.

Strange, Carolyn, \& Loo, Tina Merrill. (1997). Making good: Law and moral regulation in Canada, 1867-1939. Toronto, ON: University of Toronto Press.

Strasser, Susan. (1995). Satisfaction guaranteed: The making of the American mass market. Washington, DC: Smithsonian Institution Press.

Straw, Will. (in press). The circulatory turn. In Barbara Crow, Michael Longford, \& Kim Sawchuk (Eds.), Sampling the spectrum: The politics, practices and poetics of mobile communication. Toronto, ON: University of Toronto Press.

Taylor, William Robert. (1992). In pursuit of Gotham: Culture and commerce in New York. New York, NY: Oxford University Press.

Toronto Board of Education. (1964). A report on the Attendance Department of the Board of Education for the City of Toronto. Vertical Files: "Biography, How, Hester." Toronto, ON: Toronto District School Board Sesquicentennial Museum and Archives.

Valverde, Mariana. (2008). The age of light, soap, and water: Moral reform in English Canada, 1885-1925. Toronto, ON: University of Toronto Press.

Walkom, Thomas L. (1983). The daily newspaper industry in Ontario's developing capitalistic economy: Toronto and Ottawa, 1871-1911. Unpublished dissertation, University of Toronto, Ontario.

Warner, Michael. (2002). Publics and counterpublics. Public Culture, 14(1), 49-90.

Williams, Raymond. (1961). The long revolution. Westport, CT: Greenwood Press.

Williams, Raymond. (1968). Culture and society, 1780-1950. Harmondsworth, UK: Penguin Books.

Williams, Rosalind H. (1982). Dream worlds: Mass consumption in late nineteenth-century France. Berkeley, CA: University of California Press. 